\title{
Environmental Impacts of Rice Cultivation
}

\author{
Mariane Silva de Miranda, Marina Leite Fonseca, Alexandre Lima, \\ Tatiane Faustino de Moraes, Flávio Aparecido Rodrigues \\ Laboratório de Materiais e Superfícies, Núcleo de Ciências Ambientais (NCA), Universidade de Mogi das Cruzes, \\ Mogi das Cruzes, Brazil \\ Email: flavioar@umc.br
}

Received 27 June 2015; accepted 22 August 2015; published 25 August 2015

Copyright (C) 2015 by authors and Scientific Research Publishing Inc.

This work is licensed under the Creative Commons Attribution International License (CC BY).

http://creativecommons.org/licenses/by/4.0/

(c) (i) Open Access

\begin{abstract}
This paper describes the major environmental aspects related to the cultivation of rice. Rice is one of the most important agricultural products and it is cultivated in almost all countries in the world. Its production requires usually large flooded areas. Under these conditions, many greenhouse gases are generated, such as carbon dioxide, methane, nitrogen oxides and its derivatives. Cultivation of rice is responsible by the release of relevant amounts of these gases and contributes decisively to global warming. In this sense, the major points described here are general environmental aspects, the mechanisms of production of greenhouse gases, bioremediation, mitigation using other techniques and possible improvements of the cultivation by fertilizers and chemicals.
\end{abstract}

\section{Keywords}

\section{Rice, Environmental Aspects, Global Warming, Greenhouse Gases}

\section{Introduction}

It is well documented and recognized that many anthropogenic activities such as deforestation, energy production (especially fossil fuels consumption) and several industrial activities play an important role in global warming [1] [2]. In fact, most of world concerns seem to be associated to modern civilization aspects, such as utilization of vehicles and large-scale production. Probably, much less attention has been devoted to other "natural" sources of global heating. For instance, nowadays agricultural production is responsible for about $10 \%$ to $12 \%$ of global greenhouse gas (GHG) emissions [3] [4]. A significant part of global warming is derived from the production of gases, collectively known as greenhouse gases (GHG). Probably the most relevant gases responsible by temperature rise are carbon dioxide $\left(\mathrm{CO}_{2}\right)$, methane $\left(\mathrm{CH}_{4}\right)$ and nitrous oxide $\left(\mathrm{N}_{2} \mathrm{O}\right)$. These gases, together with other components, such as ammonium $\left(\mathrm{NH}_{3}\right)$ and other nitrogen compounds, are usually generated in animal and agricultural activities. Here we will focus on the deleterious effects of gas production due to rice harvesting. For in- 
stance, considering anthropogenic production, about $47 \%$ of methane and $58 \%$ of $\mathrm{N}_{2} \mathrm{O}$ are derived from agricultural practices [5].

Rice is one of the most important sources of food for the world population. Around 3 billion people or about $50 \%$ of human population uses rice as food and nutrients source. China is the major producer of rice in the world. In a recent study [6], the release of methane was estimated in this country. In the first place, Table 1 presents comparison of methane production according to major activities in China. It can be seen that agricultural production of methane is almost the same of energy production.

On the other hand, considering only agricultural activity, as described in Table 2, rice cultivation is responsible for about $35.6 \%$ of methane generation. In other words, rice production in China renders about $5613.1 \mathrm{Gg}$ of methane yearly.

The atmosphere concentration of methane has more than doubled from the pre-industrial era to nowadays values, varying from around $700 \mathrm{ppb}$ to $1800 \mathrm{ppb}$ [7]. It shows an effect on greenhouse 25 times superior to carbon dioxide [8].

On the other hand, nitrogen dioxides are also generated in rice fields, since nitrogen is an essential nutrient for plants. The use of fertilizer is, of course, a common practice. The effect of nitrogen oxide in global warming is also very important; it is estimated that this gas is 300 times more potent to cause greenhouse effect than carbon dioxide [9]. Furthermore, the emission of nitrogen oxide has risen up to $17 \%$ from 1990 to 2005 and this growth tends to be more dramatic due to use of fertilizers [10]. Also in 2005 about $60 \%$ of all nitrogen dioxide emissions were due to agricultural production.

\section{The Formation of Greenhouse Gases}

Greenhouse effect results in global warming and it is currently one of the main environmental concerns. The major gases involved in this phenomenon are carbon dioxide $\left(\mathrm{CO}_{2}\right)$, methane $\left(\mathrm{CH}_{4}\right)$ and nitrous oxide $\left(\mathrm{N}_{2} \mathrm{O}\right)$ [11]. It is well known that these gases are extremely important to retain heat in the atmosphere so that the temperature remains within a range of values appropriate for the existence of life [12]. Table 3 [13] summarizes the main anthropogenic sources and the lifetime in the atmosphere of the main trace gases involved in greenhouse effect.

Table 1. Activities contribution to $\mathrm{CH}_{4}$ emissions in China.

\begin{tabular}{cc}
\hline Activity & $\%$ \\
\hline Agricultural & 40.4 \\
Energy & 41.9 \\
Waste management & 17.7 \\
\hline
\end{tabular}

Table 2. Agricultural activity and its percentage on methane production.

\begin{tabular}{cc}
\hline Agricultural activity & $\%$ \\
\hline Enteric fermentation & 51.2 \\
Manure management & 10.9 \\
Rice cultivation & 35.6 \\
Field burning of agricultural residues & 2.3 \\
\hline
\end{tabular}

Table 3. Atmospheric trace gases for the significant increase in the greenhouse effect.

\begin{tabular}{ccc}
\hline & Methane $\left(\mathrm{CH}_{4}\right)$ & Nitrous oxide $\left(\mathrm{N}_{2} \mathrm{O}\right)$ \\
\hline Main source anthropogenic & $\begin{array}{c}\text { Flooded rice cultivation, livestock, } \\
\text { fossil fuels, biomass burning. }\end{array}$ & Fertilizers, land use conversion. \\
Lifetime in the Atmosphere & 10 years & 150 years \\
\hline
\end{tabular}

Adapted from [14]. 
Among these gases, probably, the most relevant is methane because of the amount released and the activity performed in the absorption of radiation. The annual global emission of methane from rice fields represent 31 $112 \mathrm{Tg}(\mathrm{Tg}=1012 \mathrm{~g})$, which means approximately $5 \%-19 \%$ of the overall methane emissions [13]. Some studies suggest the influence of factors such as solar radiation, organic fertilization, temperature, plant biomass, crop type, carbon substrate availability and soil types on the methane emissions in flooded rice fields [15] [16]. Recently [17] a study was conducted to assess the dynamics of methane emission in six different types of soil representing the irrigated rice cultivation in southern Brazil. It was suggested that the dynamics and the total quantities of $\mathrm{CH}_{4}$ emitted are influenced by the type of soil. In a similar study [18] it was found that $\mathrm{CH}_{4}$ emission is related to the amount of residues in the soil and how they were incorporated to them. Also it seems that anaerobic conditions [19] of the soil soaked stimulate the production and emissions of methane. The oxidation of $\mathrm{CH}_{4}$ is performed by methanotrophic bacterias in the oxygen zones the ecosystem (water interface-soil and rhizosphere rice). There is evidence [20] that flooded soils are cultivated under conditions conducive to the methanogenesis, due to the high carbon content and low decomposition rate of the biomass in anaerobic conditions. This process is carried out by methanogenic bacteria which have ability to use carbon compounds of low molecular weight for the production of energy. Thus, these bacteria are dependent on other hydrolytic and fermentative bacteria which reduce the molecular weight of the plant compounds. Methane is absorbed by the roots of rice plants [21] with water or gaseous, without the need for water absorption, being emitted to the atmosphere primarily by diffusion through the aerenchyma rice plants and also by gas bubbles as described in Figure 1 .

Some works [24] [25] describe between $40 \%$ and $60 \%$ of the total annual $\mathrm{N}_{2} \mathrm{O}$ emissions in the ecosystems rice-based in China occurred in the winter season. The production of $\mathrm{N}_{2} \mathrm{O}$ occurs when the floodplain soils suffers cycles of wetting and drying, in which the microorganisms actually perform the sequential processes of mineralization-nitrification-denitrification, as presented in Figure 2. It is important to note that the nitrification and denitrification processes are microbiological processes that occur in soils that contribute most to the emission of $\mathrm{N}_{2} \mathrm{O}$.

According to Gomes 2006 [26], the occurrence of nitrification and denitrification processes are determined by the soil conditions such as $\mathrm{O}_{2}$ supply, water content, temperature, $\mathrm{pH}$, organic matter, presence of vegetable residues and concentration of $\mathrm{NH}_{4}^{+}$and $\mathrm{NO}_{3}^{-}$. In the nitrification process the chemoautotrophic bacteria oxidize $\mathrm{NH}_{4}^{+}$(ammonium) in the soil producing $\mathrm{N}_{2} \mathrm{O}$ and NO. Nitrification is regulated by the presence of $\mathrm{NH}_{4}^{+} ; \mathrm{NO}_{2}$ (nitrite), $\mathrm{NO}_{3}$ (nitrate), $\mathrm{PO}_{4}^{3-}$ (phosphate), $\mathrm{O}_{2}$, soil acidity, temperature and water potential. The availability of $\mathrm{NH}_{4}^{+}$is considered a limiting factor in nitrification, which is influenced by mineralization/ immobilization, the presence of plants, cation exchange and dissemination. The $\mathrm{N}_{2} \mathrm{O}$ production by biological nitrification occurs

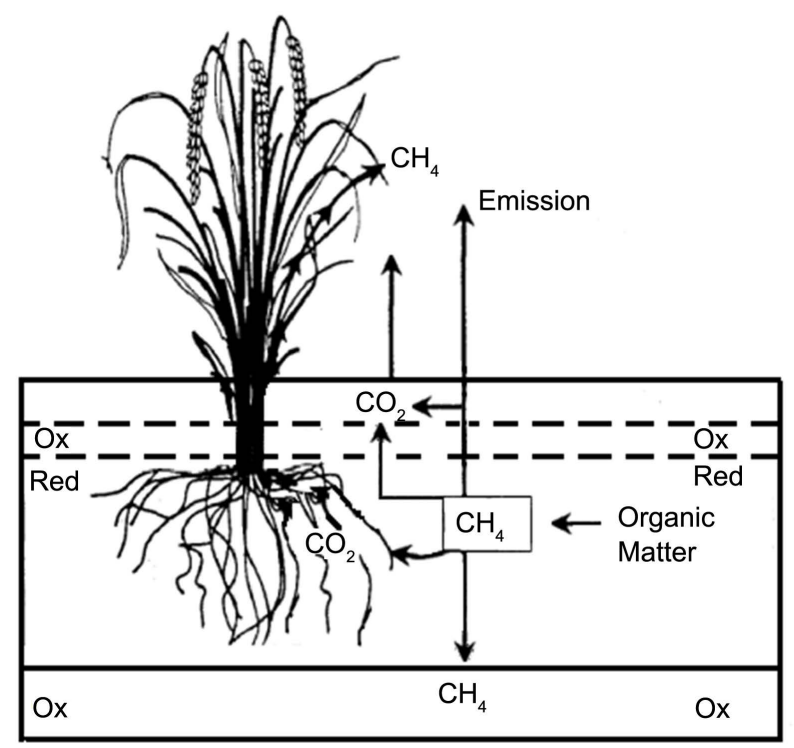

Figure 1. Flowchart adapted production and methane emission in rice fields [22]. 


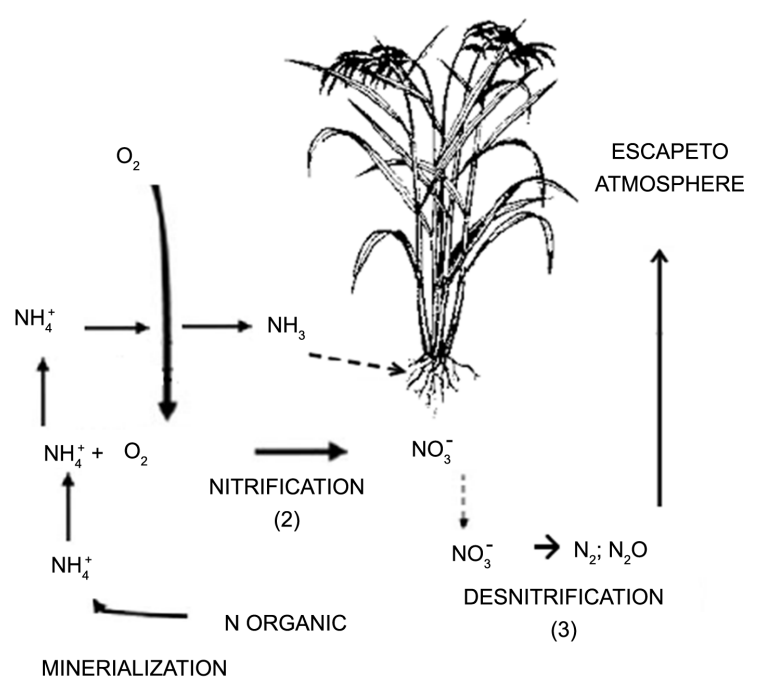

(1)

Figure 2. Dynamics of $\mathrm{N}$ in flooded soils of rice production (adapted from [23]).

when the bacteria to oxidize $\mathrm{NH}_{4}^{+}$in the absence of $\mathrm{O}_{2}, \mathrm{NO}_{3}$ use as electron acceptor. Although $\mathrm{N}_{2} \mathrm{O}$ production is possible by nitrification, high $\mathrm{N}_{2} \mathrm{O}$ emissions have been generally associated with denitrification. In the denitrification process the $\mathrm{NO}^{2-}$ and $\mathrm{NO}_{3}^{-}$ions are reduced to $\mathrm{NO}, \mathrm{N}_{2} \mathrm{O}$ or $\mathrm{N}_{2}$. Cultivation operations include, among other practices, the addition of nitrogenous fertilizer and handling conditions that can cause alternation of oxidation/reduction conditions, which may favor changes in nitrification and denitrification processes, increasing the production and emission of $\mathrm{N}_{2} \mathrm{O}$. According to Dobbie and Smith [27], the use of nitrogen fertilizer, for example, may increase the mineral $\mathrm{N}$ content in the soil and as a result, the increase of $\mathrm{N}_{2} \mathrm{O}$ emissions from soil. In a recent paper [28] it is described $\mathrm{N}_{2} \mathrm{O}$ emissions from the application of two nitrogen fertilizers (ammonium sulfate and urea) at two different doses (100 and $\left.300 \mathrm{~kg} \mathrm{~N} \mathrm{ha}^{-1}\right)$. The authors observed higher soil $\mathrm{N}_{2} \mathrm{O}$ emissions for both fertilizers when applying $300 \mathrm{~kg} \cdot \mathrm{ha}^{-1}$. On the other hand, a recent study [29] reported that $\mathrm{N}_{2} \mathrm{O}$ emissions were positively correlated with some variables such as the concentration of $\mathrm{O}_{2}$ in the soil, the groundwater and rainfall, indicating that soil moisture/aeration and availability of $\mathrm{C}$ were the main drivers for emissions of $\mathrm{N}_{2} \mathrm{O}$. The growing world population implies an increase in food production. However, the environmental aspects, such as impacts to the environment must be considered when choosing the type of food cultivation. In feed, rice plays an important role since it is the source of many important nutrients for human beings.

\section{Mitigation of Methane from Paddy Wetland: Management Strategies}

Rice crop present a different behavior if compared to other common plants; rice can even grow in soil without oxygen at root level. Organic matter is completely converted to $\mathrm{CO}_{2}$ in high-fertility soil through aerobic pathway, whereas in low-fertility soil only $7 \%$ of $\mathrm{CO}_{2}$ is produced by anaerobic pathways. Soil microorganisms require electron acceptor, usually oxygen, in their chemical reactions, especially aerobic respiration. However if oxygen is depleted other electron acceptors available are used in thermodynamically order (according to redox potential): nitrate $\left(\mathrm{NO}_{3}^{-}\right), \mathrm{Mn}(\mathrm{IV}), \mathrm{Fe}$ (III) and sulfate $\left(\mathrm{SO}_{4}^{2-}\right)$ [30] [31] also in a concentration cutoff value (Table 4).

Methane is produced strictly in anaerobic environment where the redox potential is lower than $-200 \mathrm{mV}$ [32] essential condition to methanogenic bacteria starting their activities. These bacteria are strictly anaerobic, such condition is achieved when inorganic nutrients are reduced and organic matter acetate is converted in $\mathrm{CO}_{2}$ and $\mathrm{CH}_{4}$; other bacteria group oxidizes $\mathrm{H}_{2}$ by using $\mathrm{CO}_{2}$ which is reduced to $\mathrm{CH}_{4}$ [33].

Rice cultivation generally takes place in irrigated fields to maximize crop yields but constant water supply stimulates anaerobic soil environment formation which augments the $\mathrm{CH}_{4}$ emissions [34] In fact, rice paddy is the primary anthropogenic source of methane, accounting $11 \%$ of the total $\mathrm{CH}_{4}$ anthropogenic emissions [35].

Methane emission may be affected by different factors: physiological characteristic of rice cultivars (varieties), 
Table 4. Concentration cutoff value of electron acceptors according to next most thermodynamically favorable electron accepting process.

\begin{tabular}{ccc}
\hline Species & Cutoff value $(\mu \mathrm{M})$ \\
\hline $\mathrm{O}_{2}$ & 0.5 \\
$\mathrm{NO}_{3}^{-}$ & 5 \\
$\mathrm{Mn}(\mathrm{IV})$ & 0.9 \\
$\mathrm{Fe}(\mathrm{III})$ & 8 \\
$\mathrm{SO}_{4}^{2-}$ & 1000 \\
\hline
\end{tabular}

application of both organic (manure) and inorganic fertilizers, water management, soil physicochemical conditions, soil and air temperature, compositions and activity of soil microorganisms.

Mitigation strategies to $\mathrm{CH}_{4}$ emission from rice paddies must be farm and eco-friendly, cost-effective without depleting crop yields. At farm level, some approaches (strategies) may arise: management of water, inorganic inputs and selecting rice cultivars [36] [37].

Methane may be partially oxidized in the rhizosphere converted into $\mathrm{CO}_{2}$ by aerobically oxygen released from plant roots or anaerobically by any electron acceptor available in soil. In this sense, methanogenesis in soil could be inhibited by presence of electron acceptors such as, nitrate, Mn (IV), Fe (III) and sulfate provided by inorganic fertilization or input. Nitrogen-based fertilizers are commonly applied in rice cultivation to enhance crop yields which increases carbon supply for methanogens [38] and provides larger aerenchymal pathway to methane transport from soil to the atmosphere [39] [40]. But nitrogen-based fertilizers also stimulates the growth and activity of methanotrophs $\left(\mathrm{CH}_{4}\right.$ oxidizing bacteria) inducing to a methane emission [41] [42]. The effect of nitrogen fertilizers may vary according to form and amount, mode and time of application, also the effects are not consistent (contrasting effects) they range from stimulation, neutral and inhibition.

Emission of methane during the first crop season $\mathrm{CH}_{4}$ with $\mathrm{NH}_{4}^{+}$and $\mathrm{NO}_{3}^{-}$ranged $1.2-2.6$ and $8.3-8.8 \mathrm{~g}$ $\mathrm{CH}_{4} \mathrm{~m}^{-2}$ respectively for both rice varieties. In second crop season it was observed intensification on $\mathrm{CH}_{4}$ emission vales ranges were $34.3-36.7$ and $36.6-58.6 \mathrm{~g} \mathrm{CH}_{4} \mathrm{~m}^{-2}$. Methane emission rates from the $\mathrm{NO}_{3}^{-}$amended plots were 1.5- - 3.7-fold higher than $\mathrm{NH}_{4}^{+}$amended plots during the growth period. The authors explain a higher inhibition effect of $\mathrm{CH}_{4}$ emission by ammonium sulfate rather than potassium nitrate due to easily leaching of nitrate from soil during the rainy season (period) in Chia-Yi County, Taiwan. In this study a non-fertilizer field was used as control, and then a comparison to reducing $\mathrm{CH}_{4}$ emission effect was not possible.

In this study methane emission was monitored over 4 years in a paddy rice field with typical Chinese water management (midseason aeration for a few days instead of continuous flooding) with nitrogen addition rates of 0,150 and $250 \mathrm{~kg} \mathrm{~N} \mathrm{ha}^{-1}$ (urea plus ammonium phosphate). The preliminary addition of $150 \mathrm{~kg} \mathrm{~N}^{-1}$ presented a negative effect compared to no-nitrogen amendment. It was observed average emission decreased of $38 \%$ and $49 \%$ in 150 and $250 \mathrm{~kg} \mathrm{~N} \mathrm{ha}^{-1}$, respectively. Considering that addition rate of $250 \mathrm{~kg} \mathrm{~N} \mathrm{ha}^{-1}$ is already applied in some parts of China, the authors expect that this rate could be pronounce to others sites in China as an effective management of methane emission reduction and increasing of rice crop yields [43]. In a recent works [44] [45], it was not observed a substantially methane emission reduction when nitrogen input changed from 150 to $250 \mathrm{~kg} \mathrm{~N} \mathrm{ha}^{-1}$ or more.

On the other hand [46], the contrasting effects on $\mathrm{CH}_{4}$ mitigation by $\mathrm{N}$-fertilizers could be related to nitrogen rate input. At low levels of nitrogen, great part is uptake by plants and the remaining nitrogen in soil is insufficient to oxidizing $\mathrm{CH}_{4}$ or to inhibit methanogens activity, so in this scenario methane emission is increased. On the other hand (In opposition), when higher level of N-fertilizer is applied (range $100-200 \mathrm{~kg} \mathrm{~N} \mathrm{ha}^{-1}$ ) the excess of nitrogen in soil may promote net effect in mitigation of methane emission

Although methane emission can be reduced by nitrogen-fertilizer management, this process is accompanied by a high $\mathrm{NO}_{2}$ emission, which has a 296 times higher GWP (global warming potential) than $\mathrm{CO}_{2}$ and 12 times larger than $\mathrm{CH}_{4}$ [14]. However $\mathrm{NO}_{2}$ emission is not the scope of this review. Ferric iron or $\mathrm{Fe}$ (III) is considered major soil characteristic regulating $\mathrm{CH}_{4}$ emission from rice soils [47] Methane emission is suppressed by enhancing the activity of iron reducing bacteria and inhibiting the activity of methanogens for the common electron donor. According to Silva et al. while inorganic nutrients (electron acceptors) are available (attainable), like 
Fe (III), Mn (IV) and Mn (III), the organic matter using is limited which reduce methane emission.

In a labor scale [48] could observe a net reduction of methane emission of $43 \%$ and $84 \%$ by addition of 15 and $30 \mathrm{~g}$ of ferrihydrate $/ \mathrm{kg}$ of soil over 143 days during growth and harvest period of rice in beakers. When this assay was applied in rice paddy field, [49] the $1.58 \mathrm{~kg}$ of ferrihydrate supply into $2 \times 2 \mathrm{~m}$ plot could mitigate $50 \%$ of methane emission in comparison with a no-Fe (III) supplied area.

Ferric hydroxide and ferrihydrite were used as Fe (III) source in in the field treatment over the paddy rice-winter wheat rotation cycle. The Fe (III) fertilizer was applied at the rate of 4.0 and $8.0 \mathrm{t}^{\mathrm{t}} \mathrm{ha}^{-1}$, representing medium (Fe-M) and high (Fe-H) application levels in the rice based soils of Southeast China, respectively. Compared with the control, Fe (III) fertilization decreased $\mathrm{CH}_{4}$ by $27 \%$ and $44 \%$ for the $\mathrm{Fe}-\mathrm{M}$ and $\mathrm{Fe}-\mathrm{H}$ plots, respectively. Besides mitigation $\mathrm{CH} 4$ emission from Fe (III) amended soil observed increased in rice crop yield, suggesting win-win management approach [50].

Industrial by-products with high concentration of active iron ( $\mathrm{Fe}$ ) was applied in rice paddy fields (China) in order to evaluate the mitigation potential of steel slag fertilizer in a range of $2-8 \mathrm{Mg}$ per ha. In this study was observed an overall decrease $\mathrm{CH}_{4}$ emission ranging from $26.6 \%$ to $49.3 \%$ [51].

The addition of sulfate-based fertilizers reduces methane emissions once sulfate reducing bacteria will compete with methane producing bacteria for same substrate. The methane emission from plots amended with 6.66 tons $\mathrm{ha}^{-1}$ gypsum was reduced by $55 \%$ - 70\% compared to non-amended plot [52]. Similar mitigation methane emission was also observed [53] but when phosphogypsum was applied $\mathrm{CH} 4$ emission reduced only $50 \%$ at a higher level of supplementation $\left(10.0 \mathrm{t} \cdot \mathrm{ha}^{-1}\right)$. Linquist and coworkers concluded that mitigation of $\mathrm{CH}_{4}$ emission is a sulfate rate linear regression, i.e., when there is an increase in sulfate rate is observed a decrease in methane emission.

\section{Influence of Chemicals on Gas Production}

Nitrification inhibitors (NI) are used to decrease emission of $\mathrm{N}_{2} \mathrm{O}$. The ammonia monooxygenase (AMO) is one enzyme involved in the oxidation of $\mathrm{NH}_{4}^{+}$to $\mathrm{NO}_{3}^{-}$in soils [54]. Different nitrification inhibitors of nitrous oxide $\left(\mathrm{N}_{2} \mathrm{O}\right)$ were studied in one experiment with four treatments: (a) pearled urea; (b) urea p dicyandiamide (DCD); (c) urea p Nimin; (d) p urea Karanjin. $\mathrm{CH}_{4}$ emission was significantly higher with applications of DCD and Karanjin during the rainy and dry season, respectively. $\mathrm{N}_{2} \mathrm{O}$ emission was inhibited with Nimin application more significantly during the rainy and dry seasons (69\% and $85 \%$ respectively). Applying Nimin increases methanotrophic bacterial population in the soil, and this increase may be related to the low emission of $\mathrm{CH}_{4}$. $\mathrm{In}$ this study it was concluded that, with Nimin and Karanjin, there was a decrease in soil denitrification [55].

Another experiment was conducted to study the effect of the joint application time of hydroquinone as urease inhibitor (HQ) and dicyandiamide as a nitrification inhibitor (DCD) in $\mathrm{N}_{2} \mathrm{O}$ emissions in rice fields. These results indicate more efficient inhibition on $\mathrm{N}_{2} \mathrm{O}$ emission registered to HQ and DCD applied with fertilizer at tillering stage [56].

The impact of the nitrification inhibitor in rice production, 2-chloro-6 (trichloromethyl) pyridine (CP), was studied using five treatments: CK (no N applied), N180 and N240 and their counterparts N180 + CP and N240 + $\mathrm{CP}$ ( $\mathrm{N}$ use plus $\mathrm{CP}$ ). The use of $180 \mathrm{~kg} \cdot \mathrm{ha}^{-1} \mathrm{~N}$ with $\mathrm{CP}$ and the use of $240 \mathrm{~kg} \cdot \mathrm{ha}^{-1} \mathrm{~N}$ without $\mathrm{CP}$ resulted in the same yield. Despite the increase in $\mathrm{NH}_{3}$ volatilization with $\mathrm{CP}$, and the consequent increase in indirect emissions of $\mathrm{N}_{2} \mathrm{O}$, it is estimated that $\mathrm{CP}$ has led to an overall decrease in global warming potential [57].

Use of two nitrification inhibitors was studied, viz., S-benzylisothiouronium butanoate (SBTbutanoate) and mometasone S-benzylisothiouronium (SBT-furoate) benzylisothiouronium furoate (SBT-furoate). The nitrification inhibitors used in the study increased yield and decreased global warming potential in relation to the treatment of urea [58].

A four-year field campaign was held in the Yangtze River Delta 2004-2007 to assess the effects of more $\mathrm{NH}_{4} \mathrm{H}_{2} \mathrm{PO}_{4}$ urea application on $\mathrm{CH}_{4}$ emissions in rice cultivation. For addition rate of $250 \mathrm{~kg}$ of N Ha${ }^{-1}, \mathrm{CH}_{4}$ emissions have been significantly reduced [59].

Wastewater disposal of livestock in paddy fields is a practical treatment adopted by some producers. The influence of such waste water at planting and $\mathrm{N}_{2} \mathrm{O}$ emissions was studied. Emissions of $\mathrm{N}_{2} \mathrm{O}$ cumulative varied to $\mathrm{N} 750$, the $\mathrm{N}_{2} \mathrm{O}$ emitted during the final draining, corresponded for $80 \%$ of cumulative emissions of $\mathrm{N}_{2} \mathrm{O}$ [60].

Influence of ammonia on the application of $\mathrm{N}_{2} \mathrm{O}$ emissions was also evaluated. The results revealed a trade-off between $\mathrm{CH}_{4}$ and $\mathrm{N}_{2} \mathrm{O}$ emissions influenced by the application of urea-based fertilizers, i.e., the nitro- 
gen fertilization reduced. Total $\mathrm{CH}_{4}$ and $\mathrm{N}_{2} \mathrm{O}$, expressed in carbon dioxide equivalents, were affected by rate of addition of nitrogen, with minimal emissions occurring at $250 \mathrm{~kg} \cdot \mathrm{ha}^{-1}[61]$.

A meta-analysis was performed to determine the effects of treatment medium management practices, both $\mathrm{CH}_{4}$ and $\mathrm{N}_{2} \mathrm{O}$ in rice cultivation. Low inorganic fertilizer $\mathrm{N}$ rates increased $\mathrm{CH}_{4}$ emissions by $18 \%$ relative to when no $\mathrm{N}$ fertilizer was applied, while high $\mathrm{N}$ rates decreased $\mathrm{CH}_{4}$ emissions by $15 \%$. Replacing urea with ammonium sulfate at the same, $\mathrm{N}$ rate significantly reduced $\mathrm{CH}_{4}$ emissions by $40 \%$, but might increase $\mathrm{N}_{2} \mathrm{O}$ emissions. Dicyandiamide led to lower emissions of both $\mathrm{CH}_{4}$ and $\mathrm{N}_{2} \mathrm{O}$. When compared to inorganic $\mathrm{N}$ fertilizers, farmyard manure (FYM) increased $\mathrm{CH}_{4}$ emissions and the green manure (GrM) Sesbania by $192 \%$ [62].

An assessment of the effects of different types of manure about $\mathrm{CH}_{4}$ and $\mathrm{N}_{2} \mathrm{O}$ was performed. The concentration of $\mathrm{Zn}$ and $\mathrm{Cu}$ in rice and the nitrate content in drainage water were evaluated. The experiment included the following treatments: (a) anaerobically digested sludge cattle (ADCS); (b) ADCS filtered to remove the coarse fraction of soil organic matter; (c) anaerobically digested sludge pig (ADPS); (d) chemical fertilizers (CF). The application rate was $30 \mathrm{mg} \mathrm{NH}_{4}-\mathrm{N}_{2}$. Different amounts of $\mathrm{C}$ were added to fertilization: $\mathrm{C} 725 \mathrm{~m}^{2}$ on ADCS, $352 \mathrm{~g} \cdot \mathrm{m}^{-2}$ in ADCS filtered, and $75 \mathrm{~g} \cdot \mathrm{m}^{-2}$ in ADPS. This study suggests that ADPS, containing minor amounts of $\mathrm{C}$ than ADCS can be used as an organic fertilizer in paddy field showing environmental impacts similar to chemical fertilizers (CF) [63].

Another field experiment was conducted to investigate the effect of biochar at doses of 0,10 and $40 \mathrm{t}^{\mathrm{h}} \mathrm{ha}^{-1}$ in rice productivity and $\mathrm{CH}_{4}$ and $\mathrm{N}_{2} \mathrm{O}$ with or without nitrogen fertilizer on a rice plantation. Soil $\mathrm{CH}_{4}$ emissions total $\mathrm{C}$ were increased in soils treated with biochar to $40 \mathrm{t} \cdot \mathrm{ha}^{-1}$ compared to treatments without biochar and with or without nitrogen fertilization, respectively. The results showed that biochar significantly increased rice production and reduction of $\mathrm{N}_{2} \mathrm{O}$ emissions, but increased the total $\mathrm{CH}_{4}$ emissions [64].

\section{Acknowledgements}

Authors are grateful to Fundação de Apoio ao Ensino e Pesuisa (FAEP), Universidade de Mogi das Cruzes.

\section{References}

[1] Heinke, J., Ostberg, S., Schaphoff, S., Frieler, K., Müller, C., Gerten, D., Meinshausen, M. and Lucht, M. (2013) A New Climate Dataset for Systematic Assessments of Climate Change Impacts as a Function of Global Warming. Geoscientific Model Development, 6, 1689-1703. http://dx.doi.org/10.5194/gmd-6-1689-2013

[2] Rodrigues, F.A. and Joekes, I. (2011) Cement and Industry: Sustainability, Challenges and Perspectives. Environmental Chemistry Letters, 9, 151-166. http://dx.doi.org/10.1007/s10311-010-0302-2

[3] Mogensen, L., Kristensen, T., Nielsen, N.I., Spleth, P., Henriksson, M., Swensson, C., Hessle, A. and Vestergaard, M. (2015) Greenhouse Gas Emissions from Beef Production Systems in Denmark and Sweden. Livestock Science, 174, 126-143. http://dx.doi.org/10.1016/j.livsci.2015.01.021

[4] Mosleh, M.K., Hassan, Q.K. and Chowdhury, E.H. (2015) Application of Remote Sensors in Mapping Rice Area and Forecasting Its Production: A Review. Sensors, 15, 769-791. http://dx.doi.org/10.3390/s150100769

[5] Sander, B.O., Samson, M. and Buresh, R.J. (2014) Methane and Nitrous Oxide Emissions from Flooded Rice Fields as Affected by Water and Straw Management between Rice Crops. Geoderma, 235-236, 355-362. http://dx.doi.org/10.1016/j.geoderma.2014.07.020

[6] Zhang, B. and Chen, G.Q. (2014) China's $\mathrm{CH}_{4}$ and $\mathrm{CO}_{2}$ Emissions: Bottom-Up Estimation and Comparative Analysis. Ecological Indicators, 47, 112-122. http://dx.doi.org/10.1016/j.ecolind.2014.01.022

[7] Liu, G., Yu, H., Ma, J., Xu, H., Wu, Q., Yang, J. and Zhuang, Y. (2015) Effects of Straw Incorporation along with Microbial Inoculant on Methane and Nitrous Oxide Emissions from Rice Fields. Science of the Total Environment, 518-519, 209-216. http://dx.doi.org/10.1016/j.scitotenv.2015.02.028

[8] Pramanik, P., Haque, M. and Kim, P.J. (2013) Effect of Nodule Formation in Roots of Hairy Vetch (Viciavillosa) on Mthane and Nitrous Oxide Emissions during Succeeding Rice Cultivation. Agriculture, Ecosystems and Environment, 178, 51-56. http://dx.doi.org/10.1016/j.agee.2013.06.021

[9] Suna, H., Zhang, H., Powlsond, D., Mina, J. and Shi, W. (2015) Rice Production, Nitrous Oxide Emission and Ammonia Volatilization as Impacted by the Nitrification Inhibitor 2-Chloro-6-(trichloromethyl)-pyridine. Field Crops Research, 173, 1-7. http://dx.doi.org/10.1016/j.fcr.2014.12.012

[10] Suna, W. and Huang, Y. (2012) Synthetic Fertilizer Management for China's Cereal Crops Has Reduced $\mathrm{N}_{2} \mathrm{O}$ Emissions Since the Early 2000s. Environmental Pollution, 160, 24-27. http://dx.doi.org/10.1016/j.envpol.2011.09.006

[11] IPCC (2007) Agriculture. In: Metz, B., Davidson, O.R. and Bosch, P.R., Eds., Climate Change 2007: Mitigation, Con- 
tribution of Working Group III to the Fourth Assessment Report of the Intergovernmental Panel on Climate Change, Cambridge University Press, Cambridge, 499-532.

[12] Zschornack, T., Bayer, C., Zanatta, J.A., Vieira, F.C.B. and Anghinoni, I. (2011) Mitigation of Methane and Nitrous Oxide Emissions from Flood-Irrigated Rice by No Incorporation of Winter Crop Residues into the Soil. Revista Brasileira de Ciências do Solo, 35, 623-634. http://dx.doi.org/10.1590/S0100-06832011000200031

[13] Smith, J.B., Suarez, A. and Yamin, F. (2007) Assessing Key Vulnerabilities and the Risk from Climate Change. In: Parry, M.L., Canzini, O.F., Palutikof, J.P., Van der Linden, P.J. and Hanson, C.E., Eds., Climate Change 2007: Impacts, Adaptation and Vulnerability, Contribution of Working Group II to the Fourth Assessment Report of the Intergovernmental Panel on Climate Change, Cambridge University Press, Cambridge.

[14] Lima, M.A. (2000) Emissão de gases de efeito estufa provenientes de sistemas agrícolas no Brasil. Biotecnologia Ciência e Desenvolvimento, 17, 38-43.

[15] Kaewpradit, W., Toomsan, B., Vityakon, P., Limpinuntana, V., Saenjan, P., Jogloy, S. and Cadisch, G. (2008) Regulating Mineral N Release and Greenhouse Gas Emissions by Mixing Groundnut Residues and Rice Straw under Field Conditions. European Journal of Soil Science, 59, 640-652. http://dx.doi.org/10.1111/j.1365-2389.2008.01021.x

[16] Ahmad, S., Li, C., Dai, G., Zhan, M., Wang, J., Pan, S. and Cao, C. (2009) Greenhouse Gas Emission from Direct Seeding Paddy Field under Different Rice Tillage Systems in Central China. Soil and Tillage Research, 106, 54-61. http://dx.doi.org/10.1016/j.still.2009.09.005

[17] Silva, J.T., de Sousa, R.O., Scivittaro, W.B., Buss, G.L. and da Silva, J.B. (2015) Emissões de metano no período de cultivo do arroz irrigado sob diferentes sistemas de preparo do solo. Embrapa Clima Temperado-Artigo em anais de congresso (ALICE). REUNIÃO SUL-BRASILEIRA DE CIÊNCIA DO SOLO, 10, 2014, Pelotas. Fatos e mitos em ciência do solo. Sociedade Brasileira de Ciência do Solo, Pelotas, UFPEL, 2014.

[18] Naser, H.M., Nagata, O., Tamura, S. and Hatano, R. (2007) Methane Emissions from Five Paddy Fields with Different Amounts of Rice Straw Application in Central Hokkaido, Japan. Soil Science and Plant Nutrition, 53, 95-101. http://dx.doi.org/10.1111/j.1747-0765.2007.00105.x

[19] Dalal, R.C., Allen, D.E., Livesley, S.J. and Richards, G. (2008) Magnitude and Biophysical Regulators of Methane Emission and Consumption in the Australian Agricultural, Forest, and Submerged Landscapes: A Review. Plant and Soil, 309, 43-76. http://dx.doi.org/10.1007/s11104-007-9446-7

[20] Agostinetto, D., Fleck, N.G., Rizzardi, M.A., Merotto Jr., A. and Vidal, R.A. (2001) Arroz vermelho: Ecofisiologia e estratégias de controle. Ciência Rural, 31, 341-349. http://dx.doi.org/10.1590/S0103-84782001000200026

[21] Wassmann, R., Neue, H.U., Alberto, M.C.R., Lantin, R.S., Bueno, C., Llenaresas, D. and Rennenberg, H. (1996) Fluxes and Pools of Methane in Wetland Rice Soils with Varying Organic Inputs. Environmental Monitoring and Assessment, 42, 163-173. http://dx.doi.org/10.1007/BF00394048

[22] Kimura, M. and Minami, A. (1995) Dynamics of Methane in Rice Fields: Emissions to the Atmosphere in Japan and Thailand. In: Peng, S., Ingram, K.T., Neue, H.-U. and Ziska, L.H., Eds., Climate Change and Rice, International Rice Research Institute, Thomson Press, New Delhi, 30-45.

[23] Figueiredo, N., Fareleira, P., Menino, R., Marques, P., Vargues, A. and Carranca, C. (2011) A produção de arroz em Portugal. Livro das comemorações dos, 75, 28-31.

[24] Xing, G.X. (1998) $\mathrm{N}_{2} \mathrm{O}$ Emission from Cropland in China. Nutrient Cycling in Agroecosystems, 52, $249-254$. http://dx.doi.org/10.1023/A:1009776008840

[25] Liang, W., Shi, Y., Zhang, H., Yue, J. and Huang, G.H. (2007) Greenhouse Gas Emissions from Northeast China Rice Fields in Fallow Season. Pedosphere, 17, 630-638. http://dx.doi.org/10.1016/S1002-0160(07)60075-7

[26] Gomes, J. (2006) Emissão de gases do efeito estufa e mitigação do potencial de aquecimento global por sistemas conservacionistas de manejo do solo. Thesis, Federal do Rio Grande do Sul University, Porto Alegre.

[27] Dobbie, K.E. and Smith, K.A. (2003) Impact of Different Forms of N Fertilizer on $\mathrm{N}_{2} \mathrm{O}$ Emissions from Intensive Grassland. Nutrient Cycling in Agroecosystems, 67, 37-46. http://dx.doi.org/10.1023/A:1025119512447

[28] Cai, Z.C., Xing, G.X., Yan, X.Y., Xu, H., Tsuruta, H., Yagi, K. and Minami, K. (1997) Methane and Nitrous Oxide Emissions from Rice Paddy Fields as Affected by Nitrogen Fertilisers and Water Management. Plant and Soil, 196, 7-14. http://dx.doi.org/10.1023/A:1004263405020

[29] Rochette, P., Tremblay, N., Fallon, E., Angers, D.A., Chantigny, M.H., MacDonald, J.D. and Parent, L.É. (2010) N 20 Emissions from an Irrigated and Non-Irrigated Organic Soil in Eastern Canada as Influenced by N Fertilizer Addition. European Journal of Soil Science, 61, 186-196. http://dx.doi.org/10.1111/j.1365-2389.2009.01222.x

[30] Xu, S.P., Jaffé, P.R. and Mauzerall, D.L. (2007) A Process-Based Model for Methane Emission from Flooded Rice Paddy Systems. Ecological Modelling, 205, 475-491. http://dx.doi.org/10.1016/j.ecolmodel.2007.03.014

[31] Mudge, F. and Adger, W.N. (1995) Methane Fluxes from Artificial Wetlands: A Global Appraisal. Environmental 
Management, 19, 39-55. http://dx.doi.org/10.1007/BF02472002

[32] Silva, L.S., Griebeler, G., Moterle, D.F., Bayer, C., Zschormark, T. and Pocojeski, E. (2011) Dinâmica da emissão de metano em solos sob cultivo de arroz irrigado no sul do Brasil. Revista Brasileira de Ciências do Solo, 35, 473-481. http://dx.doi.org/10.1590/S0100-06832011000200016

[33] Gauci, V., Matthews, E., Dise, N., Walter, B., Koch, D., Granberg, G. and Vile, M. (2004) Sulfur Pollution Suppression of the Wetland Methane Source in the 20th and 21st Centuries. Proceedings of the National Academy of Sciences of the United States of America, 101, 12583-12587. http://dx.doi.org/10.1073/pnas.0404412101

[34] Liu, S.Y., Zhang, Y.J., Lin, F., Zhang, L. and Zou, J.W. (2013) Methane and Nitrous Oxide Emissions from DirectSeeded and Seedling-Transplanted Rice Paddies in Southeast China. Plant and Soil, 374, 285-297. http://dx.doi.org/10.1007/s11104-013-1878-7

[35] Smith, P., Martino, D., Cai, Z.C., Gwary, D., Janzen, H., Kumar, P., McCarl, B., Ogle, S., O’Mara, F., Rice, C., Scholes, B., Sirotenko, O., Howden, M., McAllister, T., Pan, G.X., Romanenkov, V., Scheider, U., Towprayoon, S., Wattenbach, M. and Smith, J. (2008) Greenhouse Gas Mitigation in Agriculture. Philosophical Transactions of the Royal Society B, 363, 789-813. http://dx.doi.org/10.1098/rstb.2007.2184

[36] Epule, E.T., Peng, C. and Mafany, N.M. (2011) Methane Emissions from Paddy Rice Fields: Strategies towards Achieving a Win-Win Sustainability Scenario between Rice Production and Methane Emission Reduction. Journal of Sustainable Development, 4, 188-196. http://dx.doi.org/10.5539/jsd.v4n6p188

[37] Liou, R.M., Huang, S.N. and Lin, C.W. (2003) Methane Emission from Fields with Differences in Nitrogen Fertilizers and Rice Varieties in Taiwan Paddy Soils. Chemosphere, 50, 237-246. http://dx.doi.org/10.1016/S0045-6535(02)00158-3

[38] Lu, Y.H., Wassman, R., Neue, H. and Huang, C.Y. (2000) Dynamics of Dissolved Organic Carbon and Methane Emissions in a Flooded Rice Soil. Soil Science Society of American Journal, 64, 2011-2017. http://dx.doi.org/10.2136/sssaj2000.6462011x

[39] Dunfield, P. and Knowles, R. (1995) Kinetics of Inhibition of Methane Oxidation by Nitrate, Nitrite, and Ammonium in a Humisol. Applied and Environmental Microbiology, 61, 3129-3135.

[40] Gulledge, J. and Schimel, J.P. (1998) Low-Concentration Kinetics of Atmospheric $\mathrm{CH}_{4}$ Oxidation in Soil and Mechanism of $\mathrm{NH}_{4}^{+}$Inhibition. Applied and Environmental Microbiology, 64, 4291-4298.

[41] Bodelier, P.L., Roslev, P., Henckel, T. and Frenzel, P. (2000) Stimulation by Ammonium-Based Fertilizers of Methane Oxidation in Soil around Rice Roots. Nature, 403, 421-424. http://dx.doi.org/10.1038/35000193

[42] Bodelier, P.L. and Laanbroek, H.J. (2004) Nitrogen as a Regulatory Factor of Methane Oxidation in Soils and Sediments. FEMS Microbiology Ecology, 47, 265-277. http://dx.doi.org/10.1016/S0168-6496(03)00304-0

[43] Dong, H.B., Yao, Z.S., Zheng, X.H., Mei, B.L., Xie, B.H., Wang, R., Deng, J., Cui, F. and Zhu, J.G. (2011) Effect of Ammonium-Based, Non-Sulfate Fertilizers on $\mathrm{CH}_{4}$ Emissions from a Paddy Field with a Typical Chinese Water Management Regime. Atmospheric Environment, 45, 1095-1101. http://dx.doi.org/10.1016/j.atmosenv.2010.11.039

[44] Ma, J., Li, X.L., Xu, H., Han, Y., Cai, Z.C. and Yagi, K. (2007) Effects of Nitrogen Fertilizer and Wheat Straw Application on $\mathrm{CH}_{4}$ and $\mathrm{N}_{2} \mathrm{O}$ Emissions from a Paddy Rice Field. Australian Journal of Soil Research, 45, 359-367. http://dx.doi.org/10.1071/SR07039

[45] Xie, B.H., Zheng, X.H., Zhou, Z.X., Zhu, B., Chen, X., Shi, Y., Wang, Y.Y., Zhao, Z.C., Liu, C.Y., Yao, Z.S. and Zhu, J.G. (2010) Effects of Nitrogen Fertilizer on $\mathrm{CH}_{4}$ Emission from Rice Fields: Multi-Site Field Observations. Plant and Soil, 326, 393-401. http://dx.doi.org/10.1007/s11104-009-0020-3

[46] Linquist, B.A., Adviento-Borbe, M.A., Pittelkow, C.M., van Kessel, C. and van Groenigen, K.J. (2012) Fertilizer Management Practices and greenhouse gas emissions from rice systems: A quantitative review and analysis. Field Crops Research, 135, 10-21. http://dx.doi.org/10.1016/j.fcr.2012.06.007

[47] Cheng, W., Yagi, K., Akiyama, H., Nishimura, S., Sudo, S., Fumoto, T., Hasegawa, T., Hartley, A.E. and Megonigal, J.P. (2007) An Empirical Model of Soil Chemical Properties That Regulate Methane Production in Japanese Rice Paddy Soils. Journal of Environmental Quality, 36, 1920-1925. http://dx.doi.org/10.2134/jeq2007.0201

[48] Jäckel, U. and Schnell, S. (2000) Suppression of Methane Emission from Rice Paddies by Ferric Iron Fertilization. Soil Biology \& Biochemistry, 32, 1811-1814. http://dx.doi.org/10.1016/S0038-0717(00)00094-8

[49] Jäckel, U., Russo, S. and Schnell, S. (2005) Enhanced Iron Reduction by Iron Supplement: A Strategy to Reduce Methane Emission from Paddies. Soil Biology \& Biochemistry, 37, 2150-2154. http://dx.doi.org/10.1016/i.soilbio.2005.03.003

[50] Liu, S.W., Zhang, L., Liu, Q.H. and Zou, J.W. (2012) Fe(III) Fertilization Mitigating Net Global Warming Potential and Greenhouse Gas Intensity in Paddy Rice-Wheat Rotation Systems in China. Environmental Pollution, 164, 73-80. http://dx.doi.org/10.1016/j.envpol.2012.01.029 
[51] Wang, W., Lai, D.Y.F., Li, S., Kim, P.J., Zeng, C., Li, P. and Liang, Y. (2014) Steel Slag Amendment Reduces Methane Emission and Increases Rice Productivity in Subtropical Paddy Fields in China. Wetlands Ecology and Management, 22, 683-691. http://dx.doi.org/10.1007/s11273-014-9364-4

[52] Denier van der Gon, H.A.C. and Neue, H.U. (1994) Impact of Gypsum Application on the Methane Emission from a Wetland Rice Field. Global Biogeochemical Cycles, 8, 127-134. http://dx.doi.org/10.1029/94GB00386

[53] Lindau, C.W., Wickersham, P., DeLaune, R.D., Collins, J.W., Bollick, P.K., Scott, L.M. and Lambremont, E.N. (1998) Methane and Nitrous Oxide Evolution and ${ }^{15} \mathrm{~N}$ and ${ }^{226} \mathrm{Ra}$ Uptake as Affected by Application of Gypsum and Phosphogypsum to Louisiana Rice. Agriculture, Ecosystems and Environment, 68, 165-173. http://dx.doi.org/10.1016/S0167-8809(97)00154-0

[54] Ruser, R. and Schulz, R. (2015) The Effect of Nitrification Inhibitors on the Nitrous Oxide $\left(\mathrm{N}_{2} \mathrm{O}\right)$ Release from Agricultural Soils-A Review. Journal of Plant Nutrition and Soil Science, 178, 171-188. http://dx.doi.org/10.1002/jpln.201400251

[55] Datta, A. and Adhya, T. (2014) Effects of Organic Nitrification Inhibitors on Methane and Nitrous Oxide Emission from Tropical Rice Paddy. Atmospheric Environment, 92, 533-545. http://dx.doi.org/10.1016/j.atmosenv.2014.04.009

[56] Li, X.L., Zhang, G.B., Xu, H., Cai, Z.C. and Yagi, K. (2009) Effect of Timing of Joint Application of Hydroquinone and Dicyandiamide on Nitrous Oxide Emission from Irrigated Lowland Rice Paddy Field. Chemosphere, 75, $1417-$ 1422. http://dx.doi.org/10.1016/j.chemosphere.2009.02.006

[57] Sun, H.J., Zhang, H.L., Powlson, D., Min, J. and Shi, W.M. (2015) Rice Production, Nitrous Oxide Emission and Ammonia Volatilization as Impacted by the Nitrification Inhibitor 2-Chloro-6-(Trichloromethyl)-Pyridine. Field Crops Research, 173, 1-7. http://dx.doi.org/10.1016/j.fcr.2014.12.012

[58] Bhatia, A., Sasmal, S., Jain, N., Pathak, H., Kumar, R. and Singh, A. (2010) Mitigating Nitrous Oxide Emission from Soil under Conventional and No-Tillage in Wheat Using Nitrification Inhibitors. Agriculture, Ecosystems and Environment, 136, 247-253. http://dx.doi.org/10.1016/j.agee.2010.01.004

[59] Dong, H.B., Yao, Z.S., Zheng, X., Mei, B.L. and Xie, B.H. (2011) Effect of Ammonium-Based, Non-Sulfate Fertilizers on $\mathrm{CH}_{4}$ Emissions from a Paddy Field with a Typical Chinese Water Management Regime. Atmospheric Environment, 45, 1095-1101. http://dx.doi.org/10.1016/j.atmosenv.2010.11.039

[60] Riya, S., Zhou, S., Kobara, Y., Sagehashi, M., Terada, A. and Hosomi, M. (2015) Influence of Nitrogen Loading and Plant Nitrogen Assimilation on Nitrogen Leaching and $\mathrm{N}_{2} \mathrm{O}$ Emission in Forage Rice Paddy Fields Fertilized with Liquid Cattle Waste. Environmental Science and Pollution Research, 22, 5762-5771. http://dx.doi.org/10.1007/s11356-014-3811-x

[61] Yao, Z.S., Zheng, X.H., Dong, H.B., Wang, R., Mei, B.L. and Zhu, J.G. (2012) A 3-Year Record of $\mathrm{N}_{2} \mathrm{O}$ and $\mathrm{CH}_{4}$ Emissions from a Sandy Loam Paddy during Rice Seasons as Affected by Different Nitrogen Application Rates. Agriculture, Ecosystems and Environment, 152, 1-9. http://dx.doi.org/10.1016/j.agee.2012.02.004

[62] Linquist, B.A., Adviento-Borbe, M.A., Pittelkow, C.M., Kessel, C.V. and Groenigen, K.J. (2012) Fertilizer Management Practices and Greenhouse Gas Emissions from Rice Systems: A Quantitative Review and Analysis. Field Crops Research, 135, 10-21. http://dx.doi.org/10.1016/j.fcr.2012.06.007

[63] Sasada, Y., Win, K.T., Nonaka, R., Win, A.T., Toyota, K., Motobayashi, T., et al. (2011) Methane and $\mathrm{N}_{2} \mathrm{O}$ Emissions, Nitrate Concentrations of Drainage Water, and Zinc and Copper Uptake by Rice Fertilized with Anaerobically Digested Cattle or Pig Slurry. Biology and Fertility of Soils, 47, 949-956. http://dx.doi.org/10.1007/s00374-011-0601-1

[64] Zhang, A.F., Cui, L.Q., Pan, G.X., Li, L.Q., Hussain, Q., Zhang, X., et al. (2010) Effect of Biochar Amendment on Yield and Methane and Nitrous Oxide Emissions from a Rice Paddy from Tai Lake Plain, China. Agriculture, Ecosystems and Environment, 139, 469-475. http://dx.doi.org/10.1016/j.agee.2010.09.003 